\title{
NOTE ON THE GIANT ISOPOD GENUS BATHYNOMUS MILNE EDWARDS, 1879 WITH DESCRIPTION OF A NEW SPECIES
}

\author{
$\operatorname{AUTHOR}(\mathrm{S})$ : \\ Shih, Chang-tai
}

CITATION:

Shih, Chang-tai. NOTE ON THE GIANT ISOPOD GENUS BATHYNOMUS MILNE EDWARDS, 1879 WITH DESCRIPTION OF A NEW SPECIES. PUBLICATIONS OF THE SETO MARINE BIOLOGICAL LABORATORY 1972, 21(1): 31-42

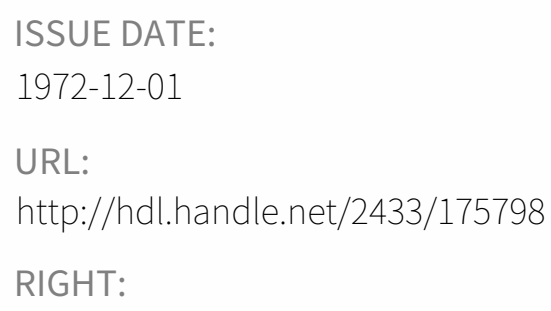




\title{
NOTE ON THE GIAN'T ISOPOD GENUS BATHYNOMUS MILNE EDWARDS, 1879 WITH DESCRIPTION OF A NEW SPECIES
}

\author{
Chang-tai SHIH \\ Canadian Oceanographic Identification Centre \\ National Museum of Natural Sciences \\ OTTAWA, Canada
}

With Text-figures 1-11 and Plates $I V-V$

\begin{abstract}
Specimens belonging to the genus Bathynomus Milne Edwards, 1879, are examined. Bathynomus decemspinosus n.sp. is described based on a specimen from the Strait of Taiwan. Bathynomus affinis Richardson, 1910, is redescribed based on four specimens from the South China Sea. Gut contents of several Bathynomus spp. from different oceans are examined.
\end{abstract}

Bathynomus Milne Edwards, 1879 belongs to the family Cirolanidae of the suborder Flabellifera. Species of this genus have 7 free pereonites and 5 free pleonites and a telson with strongly toothed posterior margin. There are free coxal plates on pereonites 2-7. All pereopods are ambulatory and pleopods swimming and respiratory. Apart from the large size, the most distinct character of the bathynomids is the development of highly ramified branchiae on the posterior surface of inner pleopod rami.

Milne Edwards (1879) had briefly described Bathynomus giganteus, the first species of this genus, based on a specimen from the Gulf of Mexico. Ortmann (1895) reported a second species, $B$. doederleini, from Sagami Bay, Japan. Milne Edwards and Bouvier (1902) contributed a monograph on Bathynomus with a full description of the two species then known and a discussion of the systematic position of the genus. Richardson (1910) added two new species, B. affinis and B. propinquus, both from the adjacent waters of the Philippines. Imaizumi (1953) found a fossil specimen of Bathynomus from the Middle Miocene of Okayama, Japan and suggested that two other fossil isopods, Palaega carteri from Bedfordshire, England (Woodward, 1870) and $P$. guadelpiensis from the Upper Cretaceous of Texas, U.S.A. (Rathbun, 1935) would probably belong to Bathynomus giganteus.

Bathynomus giganteus, well known for its large size (largest known: $356 \mathrm{~mm}$ ), has been found in the tropical Atlantic, including the Gulf of Mexico and the Caribbean Sea (Milne Edwards and Bouvier, 1902; Hansen, 1903; Richardson, 1905; Schmidt, 1931; Bullis and Thompson, 1965) and the Indian Ocean (Wood-Mason and Alcock,

Publ. Seto Mar. Biol. Lab., XXI (1), 31-42, 1972. (Article 4) 
1891 ; Annandale, 1906, 1907; Lloyd, 1907, 1908). B. doederleini is known, however, only from the North Pacific (Ortmann, 1895; Richardson, 1909, 1910). Both $B$. giganteus and $B$. doederleini are common, but never aboundant in deep-sea otter trawl catches. Because of their lack of economic value, they are usually discarded by commercial fishermen. In additon to the original record for B. affinis (Richardson, 1910), Hale (1940) reported a doubtful record of this species from south of Gabo Island, Victoria, Australia. B. propinquus has never been found since the record of Richardson (lit. cit.).

The present study includes the description of a new species of Bathynomus from the Strait of Taiwan and the description of four specimens tentatively assigned to $B$. affinis from the South China Sea. The morphological terminology mainly follows that of Wolff (1962).

I would like to thank the following persons who collected for, or made the loans of specimens to the present study: S.K. Wu, University of Michigan (1 specimen from the Strait of Taiwan); R.W. Ingle, British Museum (4 specimens from the South China Sea); T.E. Bcwman, Smithsonian Institution (type specimens of B. affinis and $B$. propinquus, and 2 young specimens of $B$. giganteus from the Gulf of Mexico); $M$. Omori, University of Tokyo (11 male and female specimens of $B$. doederleini from south of Nojima-saki, Japan); H. R. Bullis, Jr., U.S. National Marine Fisheries Services, Pascagoula, Florida (12 young to adolescent specimens of $B$. giganteus from the Gulf of Mexico); and T. Wolf, University of Copenhagen (1 specimen of $B$. giganteus from the Indian Ocean). I am grateful to Drs. Bowman, Ingle, Wolff and Wu for reviewing and criticizing the manuscript, and to my colleagues, Drs. E.L. Bousfield and D.J. Faber, who have encouraged me and offered suggestions during my preparation of the present work. Mrs. D.G. Maclellan of McGill University helped improve the English of the text.

\section{Bathynomus decemspinosus n. sp.}

Figs. 1-6, 10; Pl. IV

Material studied -1 adolescent female with rudimentary oostegites, total length $123 \mathrm{~mm}$, Strait of Taiwan west of Tungkang, Taiwan, at a depth of 70-80 m, May 8, 1965, holotype (IZAS Cat. No. 53356).

Description-Body spindle-shaped; ratio of total length (excluding median spine on posterior margin of telson) to width (excluding coxal plates) 3.15. Colour in alcohol light brown, with irregular dark and light areas.

Head, broader than long $(5: 3)$, width to that at posterior margin of pereonite 1 , $2: 3$. Frontal margin highly ridged and semicircular but slightly concave in centre where a short median process projects downward to eparate antennulae and meets dorsal margin of frontal lamina. Lateral margins embedded in pereonite 1 , almost 
straight and converging posteriorly. Posterior margin straight. Postero-lateral angles rounded. Eyes, widely separated, situated on antero-inferior surface of head, entirely concealed dorsally by frontal ridges; equilaterally triangular in shape, with concave base on lateral side of head. Frontal lamina pear-shaped, as wide as long, with straight base resting on dorsal surface of clypeus. Glypeus with anterior rounded portion protruded beyond anterior surface of frontal lamina and visible dorsally, and posterior trapezoid portion with postero-lateral angles extended laterally to partially enclose saddle-shaped labrum.

Pereon about $1 / 2$ of total length. Widths of posterior margin largest in pereonites 3 and 4, decreasing anteriorly and posteriorly. Pereonite 1 longest, length of other pereonites decreasing posteriorly. Coxal plates with carinae, postero-ventral angle square in pereonites 2 and 3 and becoming strongly produced in the rest; angle of pereonite 7 reaching to distal end of lateral angle of pleonite 2 .

Pleon, about $1 / 6$ of total length. All pleonites subequal in length. Lateral angle strongly produced in pleonites 2-4; those of pleonites $3-5$ reaching to the same posterior level.

Telson shield-shaped, about 2/9 of total length. Lateral margins almost parallel in anterior third and converging posteriorly. Length (excluding median spine) to width at posterior margin, 5:4. Median logitudinal carina obscure at anterior part but distinct and continuous to tip of median spine. Posterior margin nearly truncate with 7 evenly spaced spines. Median spine strongest, other spines becoming weaker laterally. Soft setae on posterior margin between spines.

Antennula short, reaching to distal end of antennal peduncle, with 3-jointed peduncle and flagellum of more than 50 joints (mutilated at distal end of both sides.) Antenna long, extended slightly beyond posterior margin of pereonite 3 , peduncle of 5 joints, first of which are short and almost concealed by clypeus and antennula, flagellum 64-jointed on the right and 53 on the left.

Mandible (Figs. 1 and 2). Left and right symmetrical. Incisor with three teeth, posterior tooth the largest and with a produced posterior angle. Lacinia bifid, bearing posteriorly a row of 13 short but strong spines. Molar process blade-like, length 3 times of the width, pointed at distal end, with strong denticles on medial margin. Palp with three joints, joint 1 thick, most expanded at distal end; joint 2 about 2 times as long as the first, medial margin straight, lateral margin expanded at centre with several rows of setae on thickened anterior part of lateral margin; joint 3 subequal to joint 1 in length, laminar-like, broadest at proximal end and bluntly pointed distally, lateral margin bearing a row of setae.

Maxillula (Figs. 3 and 4). Inner endite wedge-shaped lateral distal margin with nearly a square angle; medial margin bearing 4 spines at distal end, all with plumose centre portion, naked distal portion cone-shaped, proximal spine with bifid distal end; 1 small spine as shown in Fig. 3. Outer endite with 10 strong spines in 2 groups at distal part of medial margin; proximal group with 4 spines in straight row and distal 
group with 6 spines in an arch on thickened part of distal medial margin; 3 small spines as shown in Fig. 4.
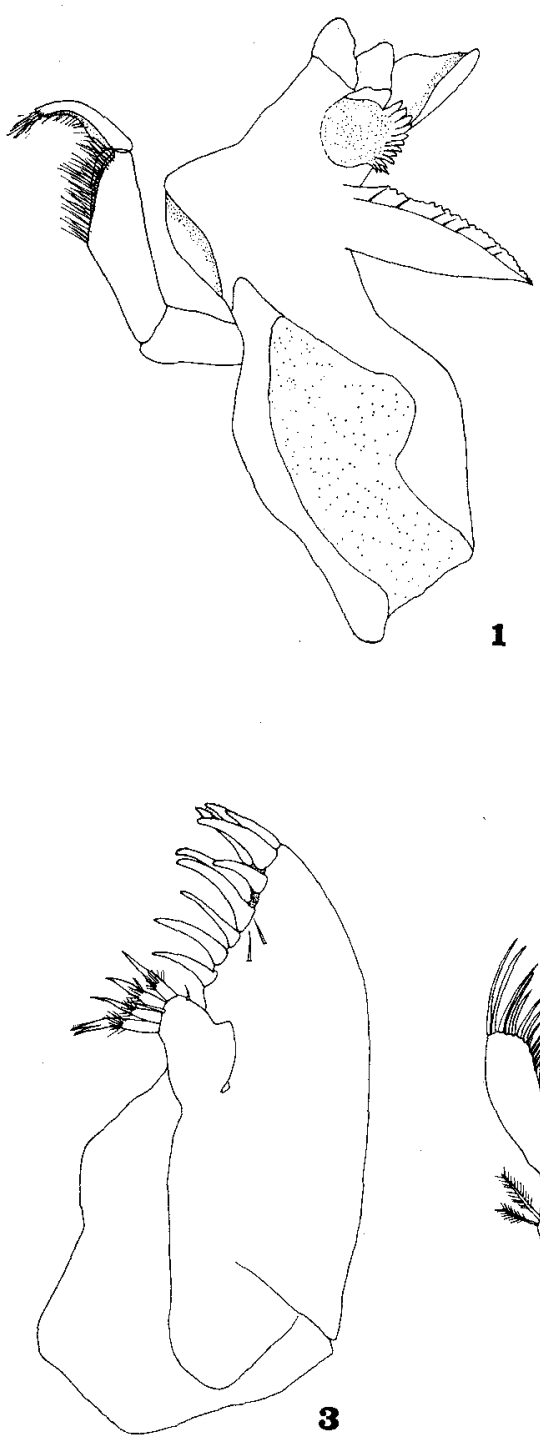

$\mathbf{3}$
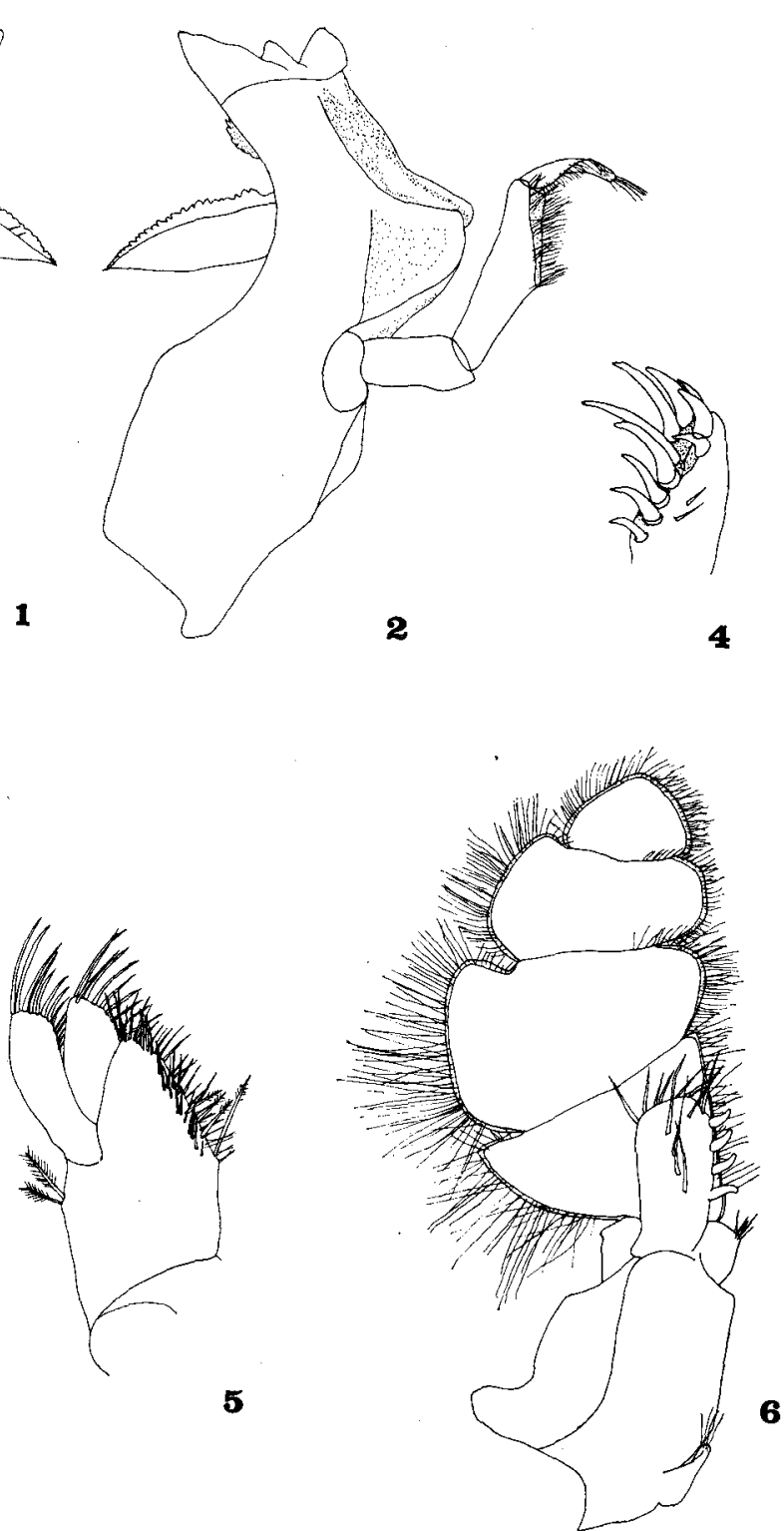

Figs. 1-6. Bathynomus decemspinosus n. sp.

1. Mandible, dorsal view. 2. Mandible, ventral view. 3. Maxillula, ventral view. 4. Maxillula, outer endite, medio-ventral view, 5. Maxilla, dorsal view, 6. Maxilliped, dorsal view. 
Maxilla (Fig. 5). Inner endite triangular, as broad as long, lateral part partially hidden under outer endite from ventral view; medial margin and dorsal surface along medial margin invested with long and short naked spines and few proximal plumose spines. Outer endite with 2 rectangular lappets. Inner lappet bearing 12 spines on distal and medial margins and 1 on dorsal surface near distal end. Ourte lappet slightly curved inward, with 13 spines on medial margin, length of spines increasing toward distal end.

Maxilliped (Fig. 6). Endite cylindrical, with rounded distal end, invested with plumose setae on distal margin and 5 isolated plumose setae on dorsal surface; medial margin provided with 4 coupling hooks. Palp with five joints, invested with plumose setae on lateral and naked setae on medial and free portion of distal margins of joints $2-5$, setae on lateral margins much longer than those on medial; a small bundle of naked spines on distal medial margin of joint 1 .

Pereopod I. Basis slightly longer than $1 / 2$ of next 5 joints combined, naked except few setae and spines on distal margin. Ischium, medial surface of antero-distal angle extended to form laminar structure covering medial part of merus. Merus, anterior margin strongly convex on proximal portion, antero-distal corner produced to form spoon-shaped projecton reaching beyond proximal end of propodus. Dactyl naked, without claw.

Pereopods II and III similar to preopod I. Antero-distal projetions of merus much elongated covering proximal half of anterior margin of propodus.

Pereopods IV-VII alike. Pereopod VI subequal to VII in length, much longer than IV and V; basis nearly as long as next 3 joints combined; ischium, merus and carpus subequal in length and similar in shape.

Pleopod I. Peduncle much broader than long, setae along medial margin; 2 groups of branchiae originating from distal margin on postero-dorsal surface extending distally to cover proximal portion of endopod. Exopod slightly shorter than endopod, narrow at proximal end, with setae along lateral, distal and distal half of medial margins. Endopod mostly covered by exopod antero-ventrally, with setae on distal and distal half of medial and lateral mergins. Pleopods 2-5 similar to but slightly larger than first.

All pereopods and pleopods are similar to those of Bathynomus doederleini which were illustrated by Milne Edwards and Bouvier (1902: pl. 7, figs. 6 and 7, pl. 8, figs. 2-6).

Uropod (Fig. 10). Medial margin of peduncle elongate, about 11/2 times length of lateral margin. Endopod longer than exopod, triangular, with lateral angle produced; medial and distal margins forming rectangular angle (about 92 ${ }^{\circ}$ ). Exopod narrow and oblong, with pointed distal angle.

The specific name, "decemspinosus", refers to the number of spines on the outer lobe of maxillula. The holotype is deposited at the Institute of Zoology, Academia Sinica, Nangkang, Taiwan. 


\section{Bathynomus affinis Richardson, 1910}

Figs. 7, 8 and $11 ; \mathrm{Pl}$. V

Material studied - 1 adolescent female with rudimentary oostegites, total length $91.5 \mathrm{~mm}$, southwest of Caluya Island, $11^{\circ} 57^{\prime} 30^{\prime \prime} \mathrm{N}, 121^{\circ} 42^{\prime} 15^{\prime \prime} \mathrm{E}$, at a depth of $570 \mathrm{~m}$ (312 fathoms), June 3, 1908, holotype (USNM Cat. No. 40908) ; 3 males with rudimentary penial processes but withourt processi masculina, total length $130.3,130.5$, and 131.0 $\mathrm{mm}, 1$ adolescent female with rudimentary oostegites, $120.5 \mathrm{~mm}$, South Ghina Sea, $19^{\circ} 38^{\prime} \mathrm{N}, 113^{\circ} 31^{\prime} \mathrm{E}$ to $19^{\circ} 35^{\prime} \mathrm{N}, 113^{\circ} 27^{\prime} 05^{\prime \prime} \mathrm{E}$, at a depth of $119-126 \mathrm{~m}$ (130-138 fathoms), December 19, 1963, all deposited at the British Museum (Natural History).
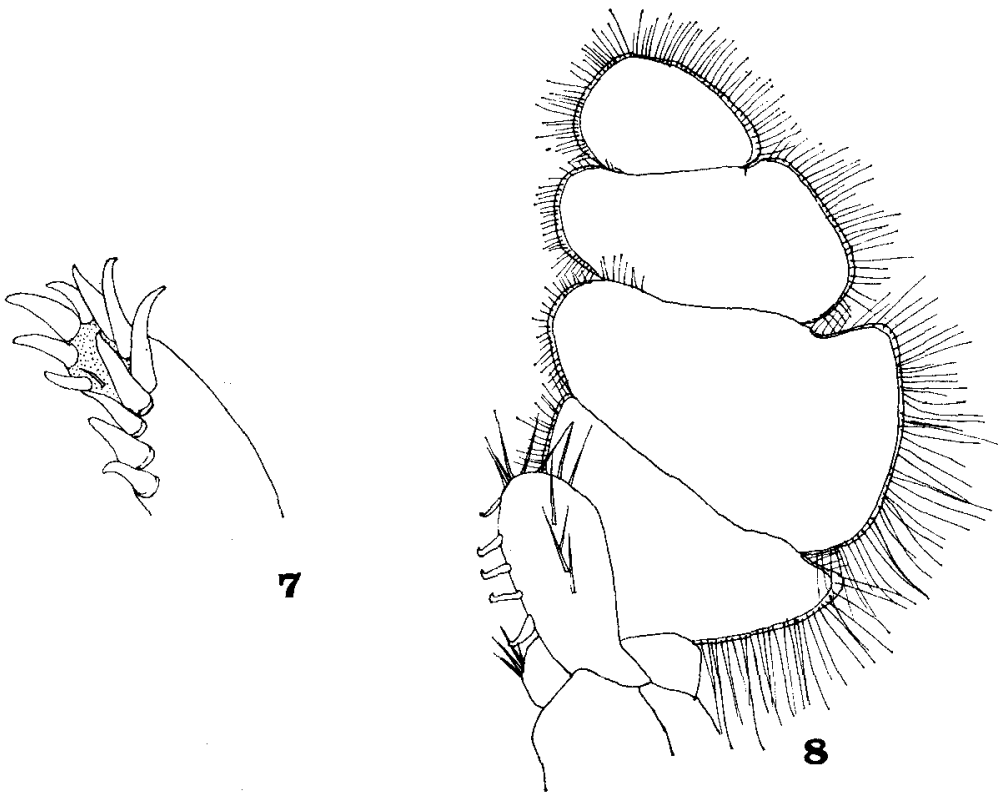

Figs. 7-8. Bathynomus affinis Richardson (South China Sea specimen).

7. Maxillula, outer endite, medio-dorsal view. 8. Maxilliped, dorsal view.

Description-Prominent specific characters based on South Ghina Sea specimens are described below.

Body spindle-shaped, ratio of total length to width, 2.40 to 2.61 .

Head broader than long, 2.28-2.50: 1, width to that at posterior margin of pereonite 1, 3:5. Frontal lamina triangular, broader than long, 5:3.

Pereon, length about $4 / 9$ of total length. Coxal plate with carinae, posterolateral angles slightly produced in pereonites 2 and 3, strongly produced in 4 to 7 .

Pleon about $1 / 5$ total length. 
Telson, about 2/7 total length. Anterior part of lateral margins converging anteriorly. Length and width at posterior margin subequal. Posterior margin slightly convex with 9 evenly spaced spines.

Antennula, reaching to 5-7 joints of antennal flagellum; with a 3-jointed peduncle and a flagellum of 65-67 joints. Antenna, reaching to the posterior margin of pereonite 3, peduncle of 5 joints, flagellum of 55 (female) and 64-65 (male).

Mandible. Lacinia bifid, bearing posteriorly a row of 11-12 stout spines.

Maxillula (Fig. 7). Inner endite bearing 4 undivided, cone-shaped spines on medial margin. Outer endite with 11 strong spines in 2 groups at distal part of medial margin; proximal group with four spines in a straight row and distal group with 7 spines in arch on thickened part of distal margin.
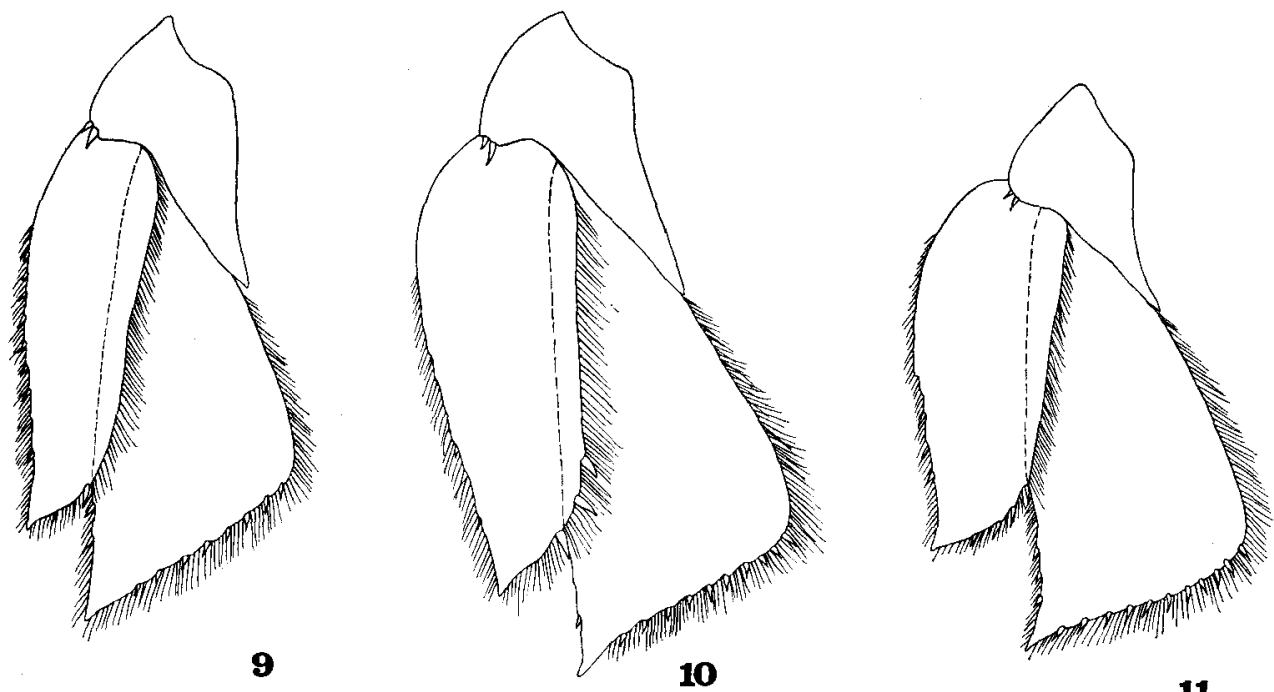

11

Fig. 9. Bathynomus doederleini Ortmann, uropod.

Fig. 10. Bathynomus decemspinosus n. sp., uropod.

Fig. 11. Bathynomus affinis Richardson (type specimen), uropod.

Maxilla. Inner endite triangular, as broad as long. Outer endite with 2 lappets, inner lappet bearing 13-15 spines on distal and medial margin and 1 spine on dorsal surface near distal end; outer lappet with 10-11 spines on distal and medial margins.

Maxilliped (Fig. 8). Endite cylindrical, distal end rounded, slightly expanded, with 5 coupling hooks on medial margin.

Uropod. Medial and distal margins of endopods forming angle of 83-86 ${ }^{\circ}$.

Remarks-The size of the South China Sea specimens is much larger than that of the type specimen. If the length ratio of the ocstegite to the basis of the corresponding pereopod is used as an indicator of the sexual development, the female specimen of the present study is obviously not much, if any, more advanced than the type. I could 
not detect any morphological differences except the size between the present specimens and the holotype and have therefore tentatively assigned the former to the species, Bathynomus affinis.

\section{Discussion}

Of the five species (including the new species herewith described) known to date within the genus Bathynomus there seems to be no doubt of the distinctiveness of the two species, $B$. giganteus and $B$. doederleini. In addition to the morphological differences that have been pointed out in the past, e.g., Ortmann (1895) and Milne Edwards and Bouvier (1902), these two species occupy different geographical areas and reach maturity at distinctly different sizes. The largest specimen of $B$. giganteus available for the present study, with a total length of $288.0 \mathrm{~mm}$, has only very rudimentary oostegites; specimens from the Indian Ocean are known to have a smaller size, e.g., mature male, $270 \mathrm{~mm}$ and mature female, $202 \mathrm{~mm}$ (Lloyd, 1908) but still far exceed the size of any other bathynomid species. On the other hand, the specimens of B. doederleini available for the present study from south of Nojima-saki, Japan, have complete development of oostegites in females as small as $89.0 \mathrm{~mm}$. All 5 male specimens of $B$. doederleini from the same collection, ranging from 93.5 to $101.5 \mathrm{~mm}$, are provided with processi masculina on pleopod 2. The number of spines on the posterior margin of the telson seems to be constant in adults of both $B$. doederleini and $B$. giganteus. Variations in number may occur in young specimens but the numbers of spines are always less than the normal number in adults. The type specimen of $B$. affinis $(91.5 \mathrm{~mm})$ is an adolescent female with rudimentary oostegites while the specimen of $B$. propinquus $(85.0 \mathrm{~mm})$ is sexually indeterminable. $B$. affinis is colse to $B$. doederleini but differs from the latter in the characters listed below:

\begin{tabular}{lll}
\hline & $\begin{array}{l}\text { B. affinis } \\
\text { (Type specimen) }\end{array}$ & $\begin{array}{l}\text { B. doederleini } \\
\text { (Specimens from } \\
\text { Nojima-saki) }\end{array}$ \\
\hline $\begin{array}{l}\text { Lateral spines on } \\
\text { posterior margin of telson }\end{array}$ & 4 pairs & 3 pairs \\
\hline $\begin{array}{l}\text { Uropod endopod: } \\
\text { medial distal angle }\end{array}$ & $83^{\circ}$ & $106^{\circ}$ \\
\hline $\begin{array}{l}\text { lateral distal angle } \\
\text { parinae on coxal } \\
\text { plates of pereonites 4-7 }\end{array}$ & abruptly produced & smoothly produced \\
\hline Carinae on telson & well marked & less well marked \\
\hline
\end{tabular}

B. porpinquus obviously is different from $B$. doederleini and $B$. affinis in having a much wider body, a wider telson with five pairs of lateral spines on the posterior margin, and a uropod with protruded medial distal angle. The proportionally wider body 
and the number of telson spines link it with $B$. giganteus. The speculation that $B$. propinquus is a young specimen of $B$. giganteus could be ruled out because, in addition to the differences listed by Richardson (1910:4), the latter species has never been known to occur in the Pacific. A ce mparison of the type of $B$. propinquus with young specimens of $B$. giganteus does not support the above speculation.

Bathynomus decemspinosus is morphologically related to $B$. doederleini. It resembles the latter in the elongate body form, in the number of spines on the posterior margin of the telson and in the degree of carination on the coxal plates and telson. It differs from $B$. doederleini in having a sharper medial distal angle $\left(92^{\circ}\right)$ of the uropod endopod, an angle which is intermediate between that of $B$. doederleini and $B$. affinis (Fig. 9-11). The doubtful specimen recorded by Hale (1940) as $B$. affinis has a body form (except the number of marginal spines on the telson) more similar to that of $B$. decemspinosus than to that of $B$. affinis. The number of spines (10) on the outer endite of the maxillula of $B$. decemspinosus is unique in the genus. These spines invariably number 11 in all other bathynomid species.

Nothing has been reported of the feeding habits of bathynomids before the present study. Several specimens of different species of this genus from different oceans were dissected and their gut contents were examined (Table 1). The presence of large quantity of radiolarians and sponge spicules seems to indicate that these isopods are scavengers. The possibility that they can attack living prey such as fish and shrimps in the natural environment is not yet certain. However, it has been known that Bathynomus attacked fishes caught in the collecting gear with it (Bowman, in litt.).

Table 1. Gut contents of Bathynomus spp. from several localities.

\begin{tabular}{lll}
\hline Species & Locality & Gut contents \\
\hline B. doederleini & South of Nojima-saki, Japan & Radiolarians, harpacticoid copeopds \\
\hline B. doederleini & South of Nojima-saki, Japan & Radiolarians, fish scales \\
\hline B. affinis & South China Sesa & $\begin{array}{l}\text { Triradiate spicules of sponge, } \\
\text { fish scales }\end{array}$ \\
\hline B. giganteus & Gulf of Mexico & $\begin{array}{l}\text { Nematodes, } \\
\text { fish scales, bones and muscles }\end{array}$ \\
\hline B. giganteus & Gulf of Mexico & $\begin{array}{l}\text { Decapod remnant (possibly a pandalid } \\
\text { shrimp-identified by A.J.G. } \\
\text { Figueira), fish scales }\end{array}$ \\
\hline
\end{tabular}

The bathynomids belong to one of the few genera of the isopods which contain species of large size (Menzies and George, 1967). Bathynomus giganteus is the largest of all isopod species. In spite of their large size, the species of the genus Bathynomis have never been found at great depths and are therefore classified as littoral-bathyal benthos by Wolff (1970). From the known records, their distribution seems to be restricted to latitudes of less than $40^{\circ}$ in both Northern and Southern Hemispheres. 


\section{REFERENCES}

Annandale, N., 1906. Two new barnacles dredged in 1905-06. Ann. Mag. nat. Hist., (7), $18: 44$.

Annandale, N., 1907. A second species of Dichelaspis from Bathynomus giganteus. Rec. Indian Mus., $1: 279-280$.

Bouvier, E.L., 1901a. La circulation branchiale chez les Bathynomus. Bull. Soc. ent. Fr., 1901, pp. 122-123.

Bouvier, E.L., 1901b. Observations nouvelles sur les Bathynomus, isopodes gigantesque des grands fonds. C.r. hebd. Séanc. Acad. Sci., Paris, 132: 643-645.

Bullis, H.R., Jr. and J.R. Thompson, 1965. Collections by the exploratory fishing vessels "Oregon", "Silver Bay", "Combat" and "Pelican" made during 1956-60 in the southwestern North Altantic. Spec. Scient. Rep. U.S. Fish Wildl. Serv. Fisheries. No. 510.

Hale, H.M., 1940. Report on the cymothoid Isopoda obtained by the F.I.S. "Endeavour" on the coast of Queensland, New South Wales, Victoria, Tasmania, and South Australia. Trans. R. Soc. S. Aust., 64(2): 288-304, pl. 18.

Hansen, H.J., 1903. The deep-sea isopod Anuropus branchiatus Bedd. and some remarks on Bathynomus giganteus A.M. Edw. J. Linn. Soc. Zoology, London, 29: 12-25, pl. 4.

Imaizumi, R., 1953. Notes on Bathynomus sp., (Crustacea) from the Miocene of Japan. Short Pap. Inst. Geol. Paleont. Tohoku Univ., 5: 84-86, pl. 12.

Lloyd, R.E., 1907. Contribution to the fauna of the Arabian Sea, with descriptions of new fishes and Crustacea. Rec. Indian Mus., 1: 1-12.

Lloyd, R.E., 1908. The internal anatomy of Bathynomus giganteus with a description of the sexually mature forms. Mem. Indian Mus., 1(2): 81-102, pls. 9-12.

Menzies, R.J. and R.Y. George, 1967. A re-evaluation of the concept of hadal or ultra-abyssal fauna. Deep-Sea Res., 14: 703-723.

Milne Edwards, A., 1879. Sur un Isopode gigantesque des grandes profondeurs de la mer. G. r. hebd. Séanc. Acad. Sci., Paris, 83: 21-23.

Milne Edwards, A. and E.L. Bouvier, 1902. Reports on the results of dredging under the supervision of Alexander Agassiz, in the Gulf of Mexico (1877-78), in the Caribbean Sea (1878-79), and along the Atlantic coast of the United States (1880), by the U.S. Coast Survey Steamer "Blake," Lieut.-Com. C.D. Sigsbee, U.S.N., and Commander J.R. Bartlett, U.S.N., commanding. XL. Les Bathynome. Mem. Mus. comp. Zool., Harv., 27(2): 129-174, pls. 1-8.

Ortmann, A., 1895. A new species of the isopod-genus Bathynomus. Proc. Acad. nat. Sci. Philad., 1894, pp. 191-193.

Rathbun, M.J., 1935. Fossil Crustacea of the Atlantic and Gulf coastal plain. Spec. Pap. geol. Soc. Am. No. 2, pp. 59-60.

Richardson. H., 1901. Key to the isopods of the Altantic coast of North America with descriptions of new and little known species. Proc. U.S. natn. Mus., 23: 493-579.

Richardson, H. 1905. A monograph of the isopods of North America. Bull. U.S. natn. Mus., 54: $1-727$.

Richardson, H., 1909. Isopods collected in the northwest Pacific by the U.S. Bureau of Fisheries steamer "Albatross" in 1906. Proc. U.S. natn. Mus., 37 (1071): 75-129.

Richardson, H., 1910. Marine isopods collected in the Philippines by the U.S. Fisheries steamer "Albatross" in 1907-08. Docums. Bur. Fish., Wash., No. 736, 44 pp.

Schmidt, W.L., 1931. Some carcinological results of the deeper water trawlings of the "Anton Dohrn", including descrition of two new species of Crustacea. Yb. Carnegie Instn. Wash., 30: 389-394.

Wolff, T., 1962. The systematics and biology of bathyal and abyssal Isopoda Asellota. Galathea Rep., 6: $1-320$.

Wolff, T., 1970. The concept of the hadal or ultra-abyssal fanua. Deep-Sea Res., 17: 983-1003.

Wood-Mason, J. and A. Alcock, 1891. Natural history notes from H.M. Indian Marine Survey steamer 'Investigator', Commander R.F. Hoskyn, R.N., commanding. No. 21. Note on the results of the last season's deep sea dredging. Ann. Mag. nat Hist., (6), 7: 258-272.

Woodward, H., 1870. Contribution to British fossil Crustacea. Geol. Mag., 7(77): 495-497, pl. 22. 


\section{EXPLANATION OF PLATES IV-V}

Plate IV. Bathynomus decemspinosus n. sp., total length $123 \mathrm{~mm}$.

Plate V. Bathynomus affinis Richardson, total length $120.5 \mathrm{~mm}$. South China Sea specimen. 
Publ. Seto Mar. Biol. Lab., XXI (1), 1972. Plate IV

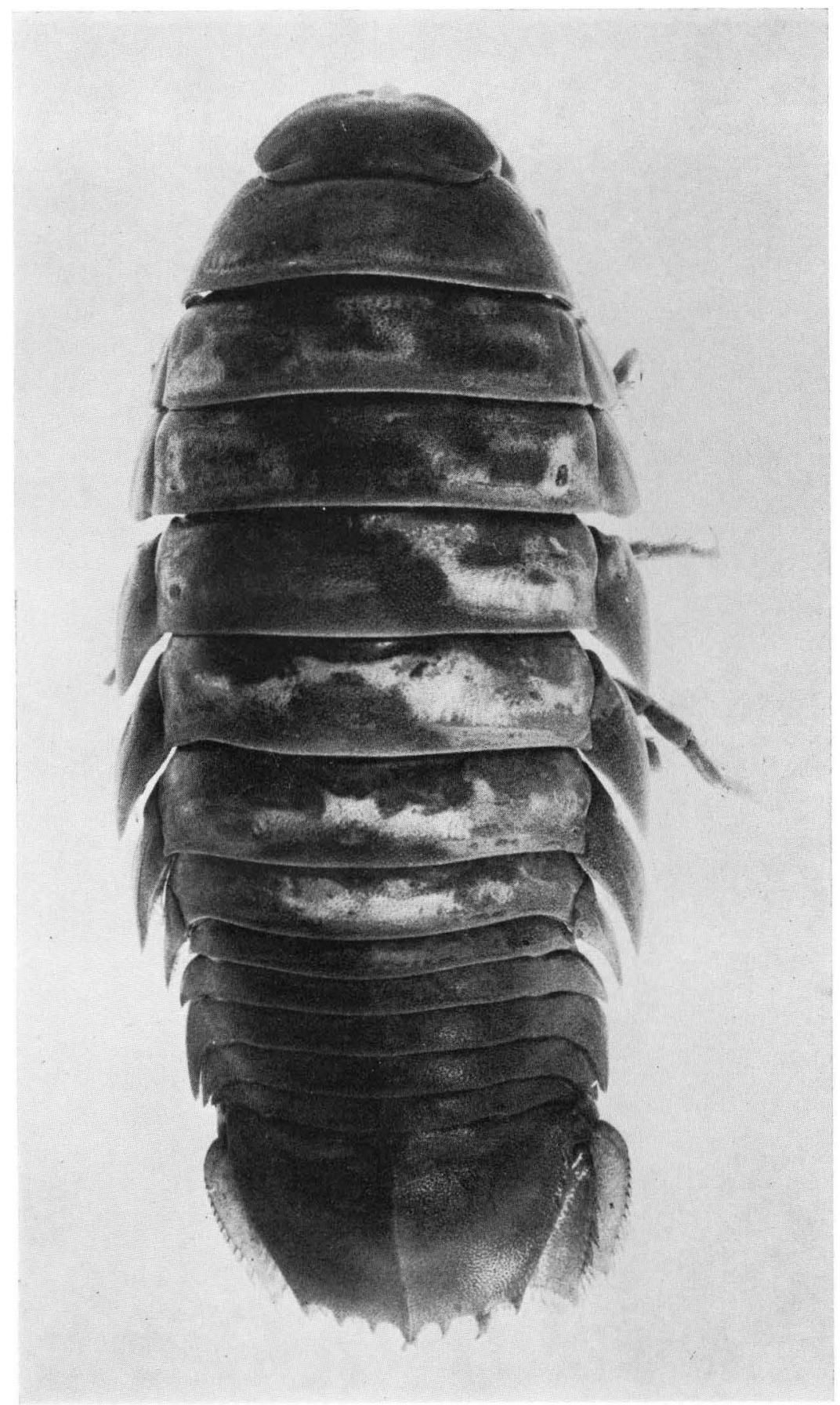

C. Sнгн: Giant Isopod Genus Bathynomus 
Publ. Seto Mar. Biol. Lab., XXI (1), 1972.

Plate V

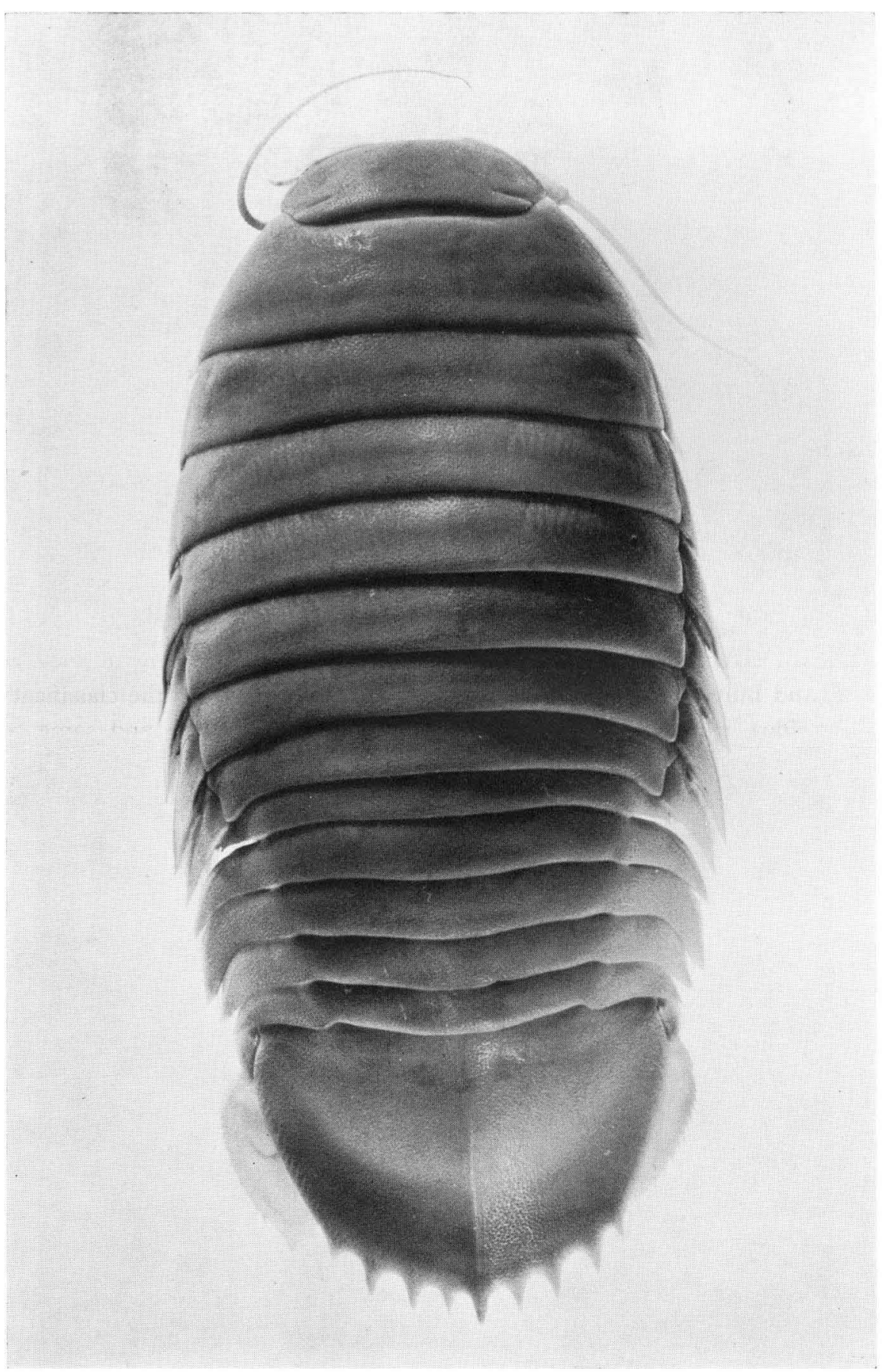

C. SHIH: Giant Isopod Genus Bathynomus 